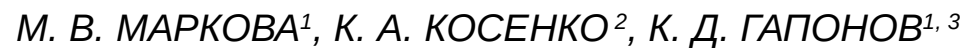

\title{
АДИКТИВНИЙ СТАТУС ПРЕДСТАВНИКІВ КОМАНДНОГО I РОБІТНИЧОГО СКЛАДУ МОРСЬКОГО ТОРГОВЕЛЬНОГО ФЛОТУ 3 РІЗНИМ РІВНЕМ ПСИХОСОЦІАЛЬНОГО СТРЕСУ
}

\author{
${ }^{1}$ Харківська медична академія післядипломної освіти, м. Харків, Україна \\ ${ }^{2}$ КНП «Одеський обласний медичний центр психічного здоров'я» \\ Одеської обласної ради, м. Одеса, Україна \\ ${ }^{3}$ Комунальне некомерційне підприємство Харківської обласної ради «Обласний наркологічний \\ диспансер», м. Харків, Україна
}

\begin{abstract}
Мета: дослідити напруженість адиктивного статусу (AC) у моряків торговельного морського фрлоту з різним рівнем психосоціального стресу (ПС) для визначення необхідності створення специфрічних для даного контингенту системних заходів з охорони їхнього психічного здоров'я.

Матеріали і методи. На засадах інформованої згоди з дотриманням принципів біоетики і деонтології протягом 2016-2019 рр. було обстежено 200 осіб представників морського торговельного фрлоту: 110 членів командного складу (КТФ) та 90 робітників (РТФ). Дослідження включало використання клініко-психопатологічного і психодіагностичного методів.

Результати. У результаті дослідження встановлено, що у представників торговельного морського фрлоту в міжрейсовий період виявлена підвищена напруженість АС за об'єктами хімічного і нехімічного походження, рівень якої прямо асоційований з вираженістю ПС. Загальним трендом динаміки АС у представників торговельного морського фрлоту, як за об'єктами хімічного, так і нехімічного походження, є збільшення інтенсивності адиктивної реалізації з наростанням психосоціального стресового навантаження.

Напруженість АС у РТФ є значно вищою, ніж у КТФ (крім роботи), в усіх межах адиктивної реалізації та діапазонах стресового навантаження. Серед осіб із низьким ПС, незалежно від професійної специфіки, напруженість АС адиктивними об'єктами і хімічного, і нехімічного походження знаходиться в межах безпечного вживання, що значно відрізняється від АС в осіб з помірним і тяжким рівнем ПС. Захопленість хімічними об'єктами (тютюн, кава/чай) в осіб із помірним рівнем ПС виражена в межах вживання зі шкідливими наслідками, з тяжким ПС - небезпечного вживання, а нехімічними - в межах вживання зі шкідливими наслідками зі зростанням показників асоційовано зі збільшенням ПС.
\end{abstract}

Висновки. Виявлені закономірності повинні враховувати при розробці специфрічних заходів психотерапії і психопрофілактики для даного контингенту, що становить перспективу цього дослідження.

КЛЮЧОВІ СЛОВА: моряки далекого плавання; командний склад торговельного морського флоту; робітники торговельного морського флоту; психосоціальний стрес; адиктивний статус.

Той фракт, що професійна діяльність мореплавства пов'язана з психічними, психосоціальними та фрізичними надзначними стресорами, на сьогодні є переконливо доведеним [14]. Специфріка праці моряків далекого плавання передбачає суттєві понаднормові навантаження за рахунок професійно зумовленого оксидативного, дизрегуляторного, емоційного та психосоціального стресу [5]. На думку Л. М. Шафрран, В. В. Голікової (2018), професійна діяльність моряків вимагає від них поєднання щонайменше двох альтернативних психофрізіологічних здатностей: з одного боку, спроможності до інтенсивних фрізичних й психоемоційних навантажень в складних навігаційних і погодних умовах, з іншого - стійкості до монотонії, гіподинамії, полідепривації в океанічному плаванні в ситуації замкненого простору та

(c) М. В. Маркова, К. А. Косенко, К. Д. Гапонов, 2020 обмеженої комунікації [15]. Дослідниці стверджують, що ці особливості морської праці лежать в основі високого ступеня психосоціального стресу (ПС), від дії якого потерпають моряки, що призводить до зниження їхньої працездатності та професійно-орієнтованої мотивації, а також розвитку ознак астенії і депресії [15].

У той же час, в спеціалізованій науковій літературі існує значна кількість досліджень, в яких стверджується, що одним зі шляхів елімінації надзначного стресового навантаження в умовах довготривалого морського рейсу стає адиктивна поведінка моряків [7-11, 14, 16].

Необхідно зазначити, що жорсткі умови медичних оглядів у проміжних портах та вимоги судновласників не дозволяють представникам торговельного морського фрлоту обирати як об'єкт адикції більшість психоактивних речовин, 
включаючи, звісно, алкоголь та інші наркотичні речовини, виключення з яких складають тютюн та кофреїн. У такому разі адиктивна амортизація стресового навантаження може відбуватися за рахунок схильності до використання об'єктів нехімічного походження та розвитку так званих поведінкових адикцій, багато з яких $€$ соціально прийнятними та не вважаються суспільством хворобливими [2]. Тому надмірна напруженість адиктивного статусу (AC) за будь-яким адиктивним об'єктом є чинником ризику щодо фрормування психічних і поведінкових розладів внаслідок їх непомірного вживання, а також збільшення кількості ризикованих позаштатних ситуацій, що можуть призвести до аварійних ситуацій техногенного характеру.

Мета роботи: дослідити напруженість адиктивного статусу в моряків торговельного морського фрлоту з різним рівнем психосоціального стресу для визначення необхідності створення специфічних для даного контингенту системних заходів з охорони їхнього психічного здоров'я.

Матеріали і методи. Для досягнення поставленої мети на засадах інфрормованої згоди 3 дотриманням принципів біоетики і деонтології протягом 2016-2019 рр. було обстежено 200 представників морського торговельного флоту: 110 членів командного складу (капітани далекого плавання, перші та другі помічники капітанів та ін.) та 90 робітників (матроси, мотористи, обслуговуючий персонал).

Усі респонденти були обстежені в період після повернення з рейсу на базі декількох медичних установ (КНП «Одеський обласний медичний центр психічного здоров'я» ООР, кафедра психіатрії, наркології та психології Одеського національного медичного університету, медичні центри «Академмарін» НУ ОМА, «Крок в нове життя», «Віта» та ін.) під час добровільного звернення за консультацією до лікаря-психіатра.

Дослідження включало використання клінікопсихопатологічного і психодіагностичного методів. Після первинного структурованого інтерв'ю оцінювали рівень ПС, випробовуваного респондентами (з використанням однойменної шкали Л. Рідера) [4]. Класичне клініко-психопатологічне обстеження пацієнтів із використанням діагностичних критеріїв MKX-10 було доповнено психометричним дослідженням 3 використанням тесту AUDIT [6] і батареї AUDIT-подібних тестів, розроблених колективом авторів під керівництвом I. В. Лінського [3] та тесту SPORT-UDIT [2].

Статистико-математичний аналіз включав формування описової статистики та аналіз розбіжностей $з$ використанням непараметричних методів.

Переважна кількість командирів була віком 36-50 років (53,6 \%), серед матросів питома вага осіб 25-35 (48,9 \%) та $36-50$ років (43,3 \%) була приблизно однаковою (рис. 1). Серед осіб старше 50 років представників командного складу (25,4 \%) було втричі більше, ніж робітників (7,8 \%).

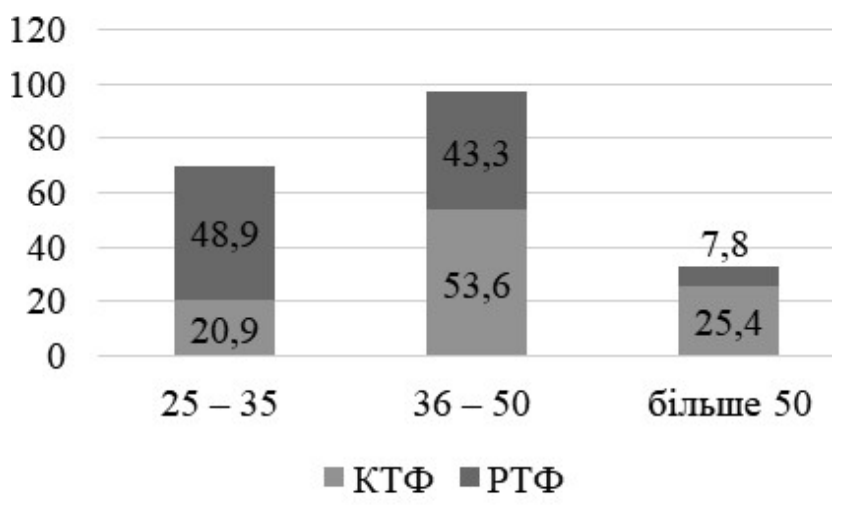

Рuc. 1. Розподіл обстежених за віком, \%.

Усі представники командного складу мали вищу освіту, більшість рядових (85,6 \%) середньоспеціальну. Більшість чоловіків в усіх групах були одружені (62,7 \% командирів та 55,5 \% матросів), інші - розлучені.

Результати дослідження та їх обговорення. Клініко-психопатологічне обстеження дозволило встановити, що серед загальної вибірки в кожній групі не менше третини осіб, які звернулися за консультацією до лікаря, не мали ознак порушення психічного здоров'я (рис. 2). Серед респондентів 3 окремими проявами психічної дезадаптації різної вираженості та клінічного наповнення було більше представників командного складу (52,7 \% КТФ проти 37,7 \% РТФ, р<0,01), а серед осіб із клінічно вираженими психічними порушеннями матросів (21,1 \% РТФ проти 16,4 \% КТФ, р<0,01). У цілому, кількість осіб із клінічно окресленими психічними розладами склала 18,0 \% від загальної вибірки, серед яких було 16,4 \% від загальної кількості КТФ і 21,1 \% від РТФ. У всіх обстежених були діагностовані розлади кластера F 43 - реакція на тяжкий стрес і адаптаційні розлади.

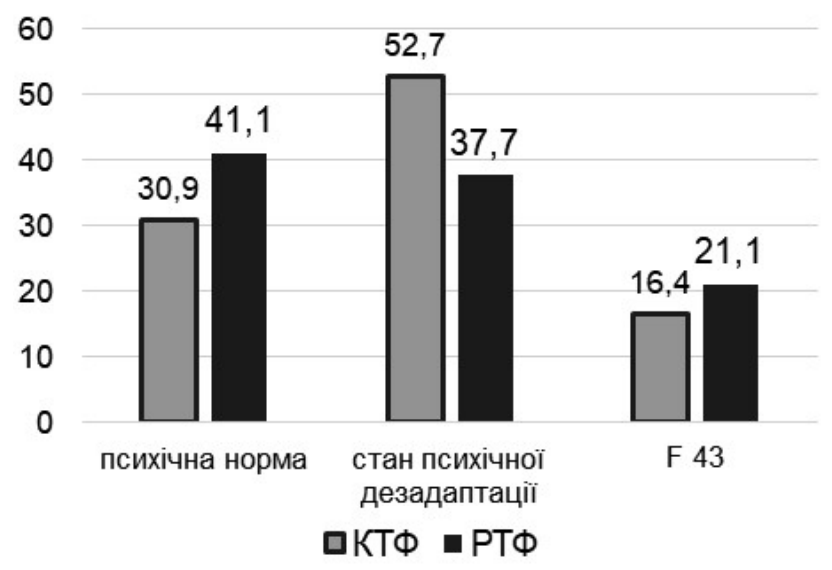

Рис. 2. Розподіл обстежених за станом психічного здоров'я, \%. 
Оцінка загальної інтенсивності стресового навантаження показала, що середні показники ПС у КТФ $(1,50 \pm 0,68)$ бала і РТФ $(1,22 \pm 0,61)$ бала перебували в межах помірних значень (1,001,99 бала), що свідчило про понаднормовість випробовуваного ними стресу (розбіжності між групами були статистично значущими, $p<0,01)$.

Порівняльна оцінка напруженості АС у міжрейсовий період у цілому по вибірці КТФ й РТФ показала такі результати (табл. 1).

Таблиця 1. Середні показники напруженості адиктивного статусу за різними адиктивними об'єктами у представників торговельного морського флоту, середній бал $\pm \mathbf{m}$

\begin{tabular}{|l|c|c|c|}
\hline $\begin{array}{c}\text { Методичний інструмент для визначення } \\
\text { напруженості АС за адиктивним об'єктом }\end{array}$ & $\begin{array}{c}\text { Командний склад, } \\
\mathrm{n}=110 \text { осіб }\end{array}$ & $\begin{array}{c}\text { Робітники, } \\
\mathrm{n=90} \text { осіб }\end{array}$ & $\mathrm{p}$ \\
\hline AUDIT & $6,9 \pm 3,59$ & $7,7 \pm 4,64$ & $>0,05$ \\
\hline TOBACCO-UDIT & $12,2 \pm 11,77$ & $14,06 \pm 13,56$ & $<0,01$ \\
\hline COFFEE (TEA)-UDIT & $13,47 \pm 7,01$ & $9,87 \pm 6,43$ & $<0,01$ \\
\hline WORKING (EDU)-UDIT & $10,59 \pm 5,96$ & $5,86 \pm 8,78$ & $<0,05$ \\
\hline INTERNET-UDIT & $8,08 \pm 5,52$ & $9,49 \pm 8,98$ & $>0,05$ \\
\hline COMP-UDIT & $7,64 \pm 4,67$ & $9,28 \pm 4,57$ & $<0,01$ \\
\hline TV-UDIT & $7,16 \pm 6,18$ & $8,61 \pm 6,77$ & $>0,05$ \\
\hline SPORT-UDIT & $6,39 \pm 5,18$ & $8,36 \pm 5,87$ & $<0,01$ \\
\hline FOOD-UDIT & $5,35 \pm 2,93$ & $7,70 \pm 3,30$ & $<0,01$ \\
\hline SHOPPING-UDIT & $6,14 \pm 3,56$ & $7,87 \pm 5,61$ & $>0,05$ \\
\hline GAMBLING-UDIT & $5,44 \pm 5,24$ & $7,46 \pm 5,50$ & $<0,01$ \\
\hline SEX-UDIT & $5,81 \pm 4,54$ & $6,73 \pm 12,14$ & $>0,05$ \\
\hline READING-UDIT & $4,47 \pm 2,76$ & $3,72 \pm 3,33$ & $<0,01$ \\
\hline
\end{tabular}

За аналізом загальних середніх показників вираженості схильності до адиктивної реалізації за об'єктами хімічного походження було з'ясовано, що, окрім алкоголю, показники вживання якого були практично в межах нормативних значень

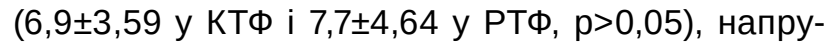
женість АС за іншими хімічними об'єктами, а саме, тютюну та кави/чаю виявилась в межах вживання зі шкідливими наслідками (7-15 балів), причому тютюнокуріння було більш вира-

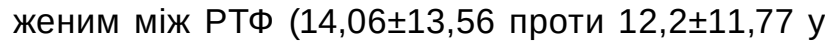
КТФ, p<0,01), а вживання кави/чаю - серед КТФ

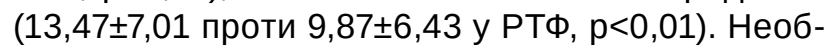
хідно зазначити, що випадків вживання інших об'єктів адикції хімічного походження у обстежених не виявлено.

У КТФ напруженість АС за об'єктами нехімічного походження була найбільше вираженою (в межах вживання зі шкідливими наслідками) за роботою $(10,59 \pm 5,96$ проти $5,86 \pm 8,78$ у РТФ, p<0,05), що свідчило про їхню схильність до працеголізму та було прогностично несприятливим маркером щодо їхнього психічного здоров'я. Окрім роботи, КТФ продемонстрували підвищені показники AC за тріадою об'єктів, пов'язаних із використанням інформаційних технологій - інтернету $(8,08 \pm 5,52)$, комп'ютерних ігор $(7,64 \pm 4,67)$ та телебачення $(7,16 \pm 6,18)$, що також виявилось характерним і для РТФ $(9,49 \pm 8,98$, р>0,05;

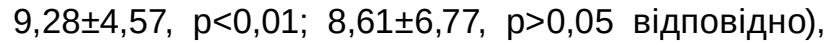
причому, у більш вираженому ступені, який, однак, не перевищував значень середньої межі вживання зі шкідливими наслідками. У РТФ, окрім вищеперелічених, спостерігали підвищені показники напруженості AC за такими поведінковими

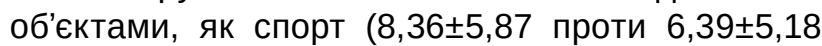
у КТФ, р<0,01), їжа $(7,70 \pm 3,30$ проти $5,35 \pm 2,93$, p<0,01), шопінг (7,87 $\pm 5,61$ проти $6,14 \pm 3,56, p>0,05)$

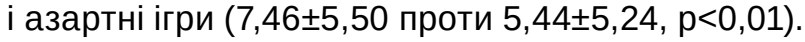

На наступному етапі роботи у кожній з категорій обстежених було виділено групи 3 низькою, помірною та тяжкою вираженістю ПС (рис. 3, 4). Серед загальної кількості обстежених низький рівень ПС виявився притаманним 30,9 \% КТФ та 41,1 \% РТФ (p<0,01); у КТФ мав місце більш високий середній показник ПС $(0,77 \pm 0,07)$, який, хоч і знаходився в амплітуді низьких значень, був вищим, порівняно з РТФ $(0,62 \pm 0,08)(p<0,05)$. Помірний рівень ПС був характерним для 52,7 \% КТФ і 37,7 \% РТФ (p<0,05). Більша вираженість ПС (в рамках помірних його значень) також була зафіксована у КТФ $(1,54 \pm 0,28$, порівняно $31,36 \pm 0,28$ у РТФ, значущість розбіжностей між ними склала p<0,05). Кількість осіб із тяжким рівнем ПС була значуще більшою серед РТФ (21,1%), порівняно 3 КТФ (16,4 \%) (p<0,01). Однак більша вираженість стресового навантаження (в рамках показників тяжкого стресу) була властива КТФ $(2,73 \pm 0,18)$, порівняно з РТФ $(2,13 \pm 0,09)$, зі значущими розбіжностями $p<0,01$. Необхідно зазначити, що, в цілому по вибірці, особи без ознак психічної дезадаптації виявились такими, що не відчували тяжкості стресового навантаження; у обстежених із дезадаптивними проявами донозологічної 
вираженості та змісту мав місце помірний рівень ПС; у пацієнтів з F 43 діагностовано тяжкий рівень ПС.

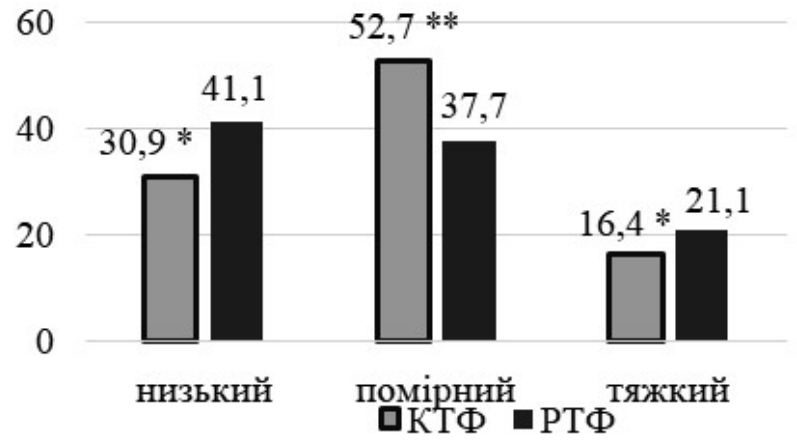

Рис. 3. Кількісний розподіл обстежених за рівнем психосоціального стресу, \%.

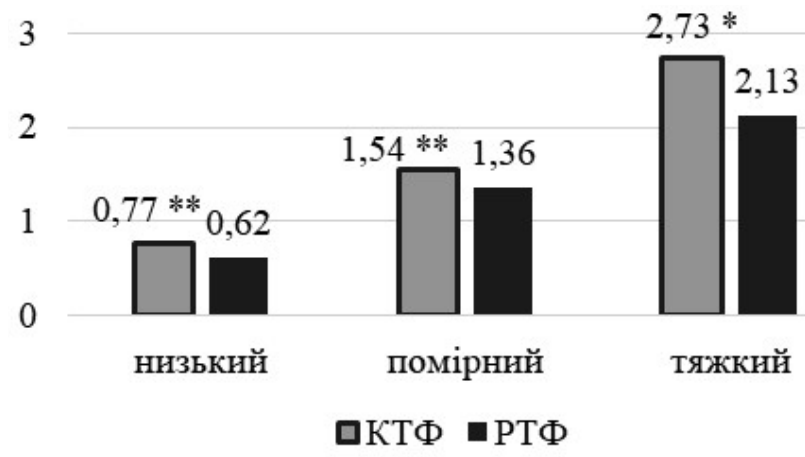

Примітка до рис. 3 і 4: рівень статистичної значущості розбіжностей при порівнянні груп: * $-p<0,01$, ** $p<0,05$.

\section{Рис. 4. Розподіл обстежених за інтенсивністю психосоціального стресу, \%.}

У результаті зіставлення інтенсивності стресового навантаження і напруженості АC встановлено, що загальним трендом динаміки AC у представників торговельного морського фрлоту 3 різним рівнем ПС як за об'єктами хімічного, так і нехімічного походження було збільшення напруженості проявів адиктивної реалізації з наростанням ПС.

Так, серед КТФ із низьким рівнем ПС (табл. 2) напруженість AC за усіма досліджуваними об'єктами була в межах відносно безпечного вживання.

Серед КТФ із помірним ПС схильність до об'єктів хімічного походження мала характер вживан-

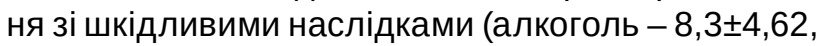

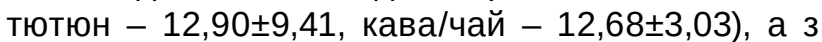
тяжким рівнем ПС - напруженість АС за тютюном $(18,28 \pm 10,07)$ і кавою/чаєм $(17,28 \pm 6,26)$ свідчила про небезпечний рівень вживання, а за алкоголем $(12,4 \pm 5,77)$ - вживання зі шкідливими наслідками. Необхідно зазначити, що розбіжності між групами з різним рівнем ПС за усіма хімічними об'єктами мали статистичну значущість від $p<0,01$ до $p<0,05$.

За поведінковими адиктивними об'єктами у КТФ 3 помірним і тяжким ПС напруженість АС не виходила за рамки вживання зі шкідливими наслідками й почасту не мала значущих розбіжностей у вираженості між цими групами. На відміну від них, при порівнянні зазначених показників із напруженістю АС в осіб з низьким ПС, розбіжності мали статистичну значущість за усіма об'єктами, крім читання.

Таблиця 2. Напруженість адиктивного статусу в КТФ із різним рівнем психосоціального стресу, середній бал \pm m

\begin{tabular}{|l|c|c|c|c|c|c|}
\hline \multirow{2}{*}{$\begin{array}{c}\text { Методичний інструмент для } \\
\begin{array}{c}\text { визначення напруженості AC } \\
\text { за адиктивним об'єктом }\end{array}\end{array}$} & \multicolumn{3}{|c|}{ Рівень ПС } & \multicolumn{3}{|c|}{$\begin{array}{c}\text { Рівень статистичної } \\
\text { значущості розбіжностей }\end{array}$} \\
\cline { 2 - 7 } AUDIT & низький & помірний & тяжкий & $\mathrm{p}_{1-2}$ & $\mathrm{p}_{1-3}$ & $\mathrm{p}_{2-3}$ \\
\hline TOBACCO-UDIT & $4,9 \pm 2,99$ & $8,3 \pm 4,62$ & $12,4 \pm 5,77$ & $<0,05$ & $<0,05$ & $<0,01$ \\
\hline COFFEE (TEA)-UDIT & $5,53 \pm 6,21$ & $12,90 \pm 9,41$ & $18,28 \pm 10,07$ & $<0,05$ & $<0,05$ & $<0,05$ \\
\hline WORKING-UDIT & $4,52 \pm 7,31$ & $12,68 \pm 3,03$ & $17,28 \pm 6,26$ & $<0,05$ & $<0,05$ & $<0,05$ \\
\hline INTERNET-UDIT & $7,12 \pm 5,68$ & $11,03 \pm 6,49$ & $11,94 \pm 4,14$ & $<0,05$ & $<0,05$ & $>0,05$ \\
\hline COMP-UDIT & $6,29 \pm 6,18$ & $8,07 \pm 5,31$ & $9,61 \pm 4,80$ & $<0,05$ & $<0,05$ & $>0,05$ \\
\hline TV-UDIT & $5,88 \pm 4,59$ & $9,69 \pm 3,75$ & $13,00 \pm 4,59$ & $<0,05$ & $<0,05$ & $<0,05$ \\
\hline SPORT-UDIT & $5,15 \pm 10,19$ & $8,72 \pm 6,71$ & $8,78 \pm 8,76$ & $<0,05$ & $<0,05$ & $>0,05$ \\
\hline FOOD-UDIT & $4,68 \pm 5,75$ & $5,34 \pm 4,93$ & $7,89 \pm 4,80$ & $>0,05$ & $<0,01$ & $<0,05$ \\
\hline SHOPPING-UDIT & $5,97 \pm 3,29$ & $10,57 \pm 2,31$ & $12,61 \pm 1,61$ & $<0,05$ & $<0,05$ & $<0,05$ \\
\hline GAMBLING-UDIT & $3,18 \pm 5,93$ & $5,40 \pm 6,14$ & $10,33 \pm 7,69$ & $<0,05$ & $<0,05$ & $<0,05$ \\
\hline SEX-UDIT & $3,24 \pm 9,03$ & $5,44 \pm 9,74$ & $8,50 \pm 6,06$ & $<0,05$ & $<0,05$ & $<0,05$ \\
\hline READING-UDIT & $4,09 \pm 8,26$ & $6,48 \pm 10,56$ & $8,11 \pm 13,43$ & $>0,05$ & $<0,05$ & $<0,05$ \\
\hline
\end{tabular}

Примітка тут і далі: $\mathrm{p}_{1-2}$ - рівень статистичної значущості розбіжностей при порівнянні груп з низьким і помірним рівнем стресу; $p_{1-3}$ - рівень статистичної значущості розбіжностей при порівнянні груп з низьким і тяжким рівнем стресу; $p_{2-3}$ - рівень статистичної значущості розбіжностей при порівнянні груп з помірним і тяжким рівнем стресу. 
Розподіл показників напруженості АС у РТФ (табл. 3) із низьким рівнем ПС продемонстрував схожу з КТФ тенденцію: за всіма адиктивними об'єктами середні значення виявились в межах безпечного вживання.

У осіб з помірним рівнем ПС адиктивна реалізація за усіма хімічними та більшістю нехімічних об'єктів (крім шопінгу та читання) була в амплітуді вживання зі шкідливими наслідками, що мало значущі розбіжності (від $p<0,01$ до $p<0,05) 3$ групою з низьким рівнем ПС. У РТФ, які випробовували тяжке стресове навантаження, напруженість AC за тютюном $(18,58 \pm 13,26)$ і кавою/чаєм $(18,37 \pm 3,53)$ виявилась в рамках небезпечного вживання, а за практично усіма об'єктами нехімічного походження (окрім читання) - в межах вживання зі шкідливими наслідками (розбіжності між ними і групою з низьким ПС були значущими за усіма об'єктами, з помірним - окрім роботи, інтернету та спорту, від $p<0,01$ до $p<0,05)$.

Таблиця 3. Напруженість адиктивного статусу в РТФ з різним рівнем психосоціального стресу, середній бал \pm m

\begin{tabular}{|l|c|c|c|c|c|c|}
\hline \multirow{2}{*}{$\begin{array}{c}\text { Методичний інструмент для } \\
\begin{array}{c}\text { визначення напруженості AC } \\
\text { за адиктивним об'єктом }\end{array}\end{array}$} & \multicolumn{3}{|c|}{ Рівень ПС } & \multicolumn{3}{|c|}{$\begin{array}{c}\text { Рівень статистичної } \\
\text { значущості розбіжностей }\end{array}$} \\
\cline { 2 - 7 } & низький & помірний & тяжкий & $p_{1-2}$ & $p_{1-3}$ & $p_{2-3}$ \\
\hline AUDIT & $5,7 \pm 1,88$ & $9,9 \pm 1,03$ & $14,3 \pm 2,66$ & $<0,01$ & $<0,05$ & $<0,01$ \\
\hline TOBACCO-UDIT & $7,11 \pm 7,98$ & $15,50 \pm 12,17$ & $18,58 \pm 13,26$ & $<0,05$ & $<0,05$ & $<0,01$ \\
\hline COFFEE (TEA)-UDIT & $6,97 \pm 5,27$ & $8,26 \pm 4,57$ & $18,37 \pm 3,53$ & $<0,01$ & $<0,05$ & $<0,05$ \\
\hline WORKING-UDIT & $7,59 \pm 3,15$ & $10,65 \pm 8,79$ & $10,05 \pm 7,35$ & $<0,05$ & $<0,05$ & $>0,05$ \\
\hline INTERNET-UDIT & $6,42 \pm 7,14$ & $11,74 \pm 8,34$ & $10,41 \pm 9,97$ & $<0,05$ & $<0,01$ & $>0,05$ \\
\hline COMP-UDIT & $7,08 \pm 3,92$ & $11,38 \pm 3,67$ & $14,16 \pm 0,37$ & $<0,01$ & $<0,05$ & $<0,01$ \\
\hline TV-UDIT & $4,63 \pm 3,80$ & $10,85 \pm 7,25$ & $13,46 \pm 9,05$ & $<0,01$ & $<0,01$ & $<0,01$ \\
\hline SPORT-UDIT & $6,06 \pm 5,45$ & $9,68 \pm 6,52$ & $11,05 \pm 4,96$ & $<0,05$ & $<0,05$ & $>0,05$ \\
\hline FOOD-UDIT & $7,84 \pm 2,78$ & $9,44 \pm 2,45$ & $13,79 \pm 1,51$ & $<0,05$ & $<0,05$ & $<0,05$ \\
\hline SHOPPING-UDIT & $4,59 \pm 3,93$ & $5,12 \pm 6,52$ & $13,68 \pm 5,22$ & $>0,05$ & $<0,05$ & $<0,05$ \\
\hline GAMBLING-UDIT & $5,22 \pm 7,26$ & $7,76 \pm 6,39$ & $10,00 \pm 7,79$ & $<0,01$ & $<0,05$ & $<0,05$ \\
\hline SEX-UDIT & $6,03 \pm 4,88$ & $9,56 \pm 14,67$ & $11,47 \pm 4,92$ & $<0,05$ & $<0,05$ & $<0,05$ \\
\hline READING-UDIT & $2,73 \pm 3,49$ & $4,26 \pm 2,50$ & $4,68 \pm 3,93$ & $>0,05$ & $>0,05$ & $>0,05$ \\
\hline
\end{tabular}

Порівняльний аналіз напруженості АС у КТФ і РТФ з різним рівнем ПС довів наступне (табл. 4). Напруженість АC серед осіб із низьким рівнем ПС була значуще більшою у РТФ, порівняно 3 КТФ (p<0,01), за виключенням роботи, інтернету і читання, за якими розбіжності не мали статистичної значущості. Схожа тенденція зберігалася і при вивченні динаміки АC у осіб з помірним і тяжким ПС. У РТФ 3 помірним ПС напруженість AC переважно за усіма адиктивними об'єктами була значуще вищою (від $p<0,01$ до $p<0,05$ ), ніж у КТФ, в яких захоплення роботою було виражене більше $(p<0,01)$, а за такими об'єктами, як їжа, шопінг і читання - значущих розбіжностей не виявлено. Серед осіб з тяжким рівнем стресу за усіма об'єктами хімічного походження (алкоголь $p<0,05$, інші $-p<0,01)$ та такими поведінковими, як телебачення $(p<0,05)$, спорт $(p<0,01)$, азартні ігри $(p<0,05)$ і секс $(p<0,01)$ - напруженість AC була значуще вищою у РТФ, за роботою - у КТФ $(p<0,01)$.

\section{Висновки}

У представників торговельного морського флоту в міжрейсовий період встановлена підвищена напруженість АС за об'єктами хімічного і нехімічного походження, рівень якої прямо асоційований з вираженістю ПС.

Серед хімічних об'єктів вживання зі шкідливими наслідками характерно для споживання тютюну та кави/чаю, причому тютюнокуріння більш виражене у РТФ (p<0,01), а вживання кави/чаю - серед КТФ $(p<0,01)$. 3 нехімічних залежностей рівень вживання зі шкідливими наслідками встановлено за об'єктами, пов'язаними з використанням інорормаційних технологій (інтернет, комп'ютерні ігри, телебачення), що притаманне усім обстеженим, незалежно від специфіки професійної діяльності. У РТФ, окрім вищеперелічених, має місце вживання зі шкідливими наслідками таких об'єктів, як спорт $(p<0,01)$, їжа $(p<0,01)$, азартні ігри $(p<0,01)$. У КТФ напруженість AC серед нехімічних об'єктів найбільше виражена за роботою, що свідчить про їхню схильність до працеголізму та $€$ прогностично несприятливим маркером щодо їхнього психічного здоров'я.

Загальним трендом динаміки АC у представників торговельного морського фрлоту як за об'єктами хімічного, так і нехімічного походження 
Таблиця 4. Порівняння напруженості адиктивного статусу в КТФ і РТФ з різним рівнем психосоціального стресу, середній бал \pm m

\begin{tabular}{|c|c|c|c|c|c|c|}
\hline \multirow{3}{*}{$\begin{array}{c}\text { Методичний } \\
\text { інструмент для } \\
\text { визначення } \\
\text { напруженості АС за } \\
\text { адиктивним об'єктом }\end{array}$} & \multicolumn{6}{|c|}{ Рівень ПС } \\
\hline & \multicolumn{2}{|c|}{ низький } & \multicolumn{2}{|c|}{ помірний } & \multicolumn{2}{|c|}{ тяжкий } \\
\hline & КТФ & РТФ & КТФ & РТФ & КТФ & РТФ \\
\hline AUDIT & $4,9 \pm 2,99^{*}$ & $5,7 \pm 1,88$ & $8,3 \pm 4,62^{\star}$ & $9,9 \pm 1,03$ & $12,4 \pm 5,77^{\star \star}$ & $14,3 \pm 2,66$ \\
\hline TOBACCO-UDIT & $5,53 \pm 6,21^{*}$ & $7,11 \pm 7,98$ & $12,90 \pm 9,41^{\star *}$ & $15,50 \pm 12,17$ & $18,28 \pm 10,07^{*}$ & $18,58 \pm 13,26$ \\
\hline COFFEE (TEA)-UDIT & $4,52 \pm 7,31^{*}$ & $6,97 \pm 5,27$ & $12,68 \pm 3,03^{\star \star}$ & $8,26 \pm 4,57$ & $17,28 \pm 6,26^{*}$ & $18,37 \pm 3,53$ \\
\hline WORKING-UDIT & $7,12 \pm 5,68$ & $7,59 \pm 3,15$ & $11,03 \pm 6,49^{\star}$ & $10,65 \pm 8,79$ & $11,94 \pm 4,14^{\star}$ & $10,05 \pm 7,35$ \\
\hline INTERNET-UDIT & $6,29 \pm 6,18$ & $6,42 \pm 7,14$ & $8,07 \pm 5,31^{\star *}$ & $11,74 \pm 8,34$ & $9,61 \pm 4,80$ & $10,41 \pm 9,97$ \\
\hline COMP-UDIT & $5,88 \pm 4,59^{*}$ & $7,08 \pm 3,92$ & $9,69 \pm 3,75^{\star}$ & $11,38 \pm 3,67$ & $13,00 \pm 4,59$ & $14,16 \pm 0,37$ \\
\hline TV-UDIT & $5,15 \pm 10,19$ & $4,63 \pm 3,80$ & $8,72 \pm 6,71^{*}$ & $10,85 \pm 7,25$ & $8,78 \pm 8,76^{* *}$ & $13,46 \pm 9,05$ \\
\hline SPORT-UDIT & $4,68 \pm 5,75^{*}$ & $6,06 \pm 5,45$ & $5,34 \pm 4,93^{* *}$ & $9,68 \pm 6,52$ & $7,89 \pm 4,80^{*}$ & $11,05 \pm 4,96$ \\
\hline FOOD-UDIT & $5,97 \pm 3,29^{*}$ & $7,84 \pm 2,78$ & $10,57 \pm 2,31$ & $9,44 \pm 2,45$ & $12,61 \pm 1,61$ & $13,79 \pm 1,51$ \\
\hline SHOPPING-UDIT & $3,18 \pm 5,93^{*}$ & $4,59 \pm 3,93$ & $5,40 \pm 6,14$ & $5,12 \pm 6,52$ & $10,33 \pm 7,69$ & $13,68 \pm 5,22$ \\
\hline GAMBLING-UDIT & $3,24 \pm 9,03^{*}$ & $5,22 \pm 7,26$ & $5,44 \pm 9,74^{*}$ & $7,76 \pm 6,39$ & $8,50 \pm 6,06^{* *}$ & $10,00 \pm 7,79$ \\
\hline SEX-UDIT & $4,09 \pm 8,26^{*}$ & $6,03 \pm 4,88$ & $6,48 \pm 10,56^{\star *}$ & $9,56 \pm 14,67$ & $8,11 \pm 13,43^{*}$ & $11,47 \pm 4,92$ \\
\hline READING-UDIT & $3,65 \pm 2,84$ & $2,73 \pm 3,49$ & $4,72 \pm 2,77$ & $4,26 \pm 2,50$ & $5,22 \pm 2,32$ & $4,68 \pm 3,93$ \\
\hline
\end{tabular}

$€$ збільшення інтенсивності адиктивної реалізації 3 наростанням психосоціального стресового навантаження.

Напруженість АС у РТФ є значуще вищою, ніж у КТФ (крім роботи), в усіх межах адиктивної реалізації та діапазонах стресового навантаження.

Серед осіб із низьким ПС, незалежно від професійної специфіки, напруженість АС адиктивними об'єктами і хімічного, і нехімічного походження знаходиться в межах безпечного вживання, що значуще відрізняється від АС у осіб 3 помірним і тяжким рівнем ПС.

Захопленість хімічними об'єктами (тютюн, кава/чай) у осіб з помірним рівнем ПС виражена в межах вживання зі шкідливими наслідками, 3 тяжким ПС - небезпечного вживання, а нехімічними - в межах вживання зі шкідливими наслідками зі зростанням показників асоційовано зі збільшенням ПС.

Перспективи подальших досліджень. Вираженість ПС є важливим фрактором, що визначає особливості АС у представників торговельного морського фрлоту. Виявлені закономірності повинні враховувати при розробці специфрічних заходів психотерапії і психопрофрілактики для даного контингенту, що становить перспективу цього дослідження.

\section{Список літератури}

1. Маркова М. В. Порушення здоров'я сім'ї та аддиктивна поведінка у жінок (механізми фрормування, взаємозв'язки, система психологічної корекції) / М. В. Маркова, М. В. Савіна // Fundamental and Applied Researches in Practice of Leading Scientific Schools. - 2018. - № 25 (1). - C. 89-108.

2. Маркова М. В. Тест для виявлення розладів, пов'язаних з захопленістю спортом (фітнесом) SPORT-UDIT (версія «самозвіт») для непрофресіоналів : свідоцтво про реєстрацію авторського права на твір від 24.02.2017р. № 70682 I М. В. Маркова, М. В. Савіна.

3. Метод комплексной оценки аддиктивного статуса индивида и популяции с помощью системы AUDIT-подобныX тестов / И. В. Линский, А. И. Минко, А. Ф. Артемчук [и др.] // Вісник психіатрії та психофрармакотерапії. - 2009. № 2 (16). - С. 56-70.

4. Спосіб діагностики клінічної специфіки і прогнозу перебігу алкогольної залежності у осіб з різним психотравматичним досвідом і рівнем психосоціального стресу / К. Д. Гапонов, І. К. Сосін, О. Ю. Гончарова, М. В. Маркова // Інформаційний лист МОЗ України № 249-2018. - 4 с.

5. Шафрран Л. М. Фізіолого-гігієнічні особливості професійної діяльності моряків спеціалізованого фрлоту / Л. М. Шафран, В.В.Голікова // Український журнал $з$ проблем медицини праці. - 2014. - № 3 (40). - С. 29 -39.

6. AUDIT. Alcohol Use Disorders Identification Test / Th. F. Babor, J. C. Higgins-Biddle, J. B. Saunders, M. G. Monteiro // WHO/MSD/MSB/01.6a Original: English Distribution: General. - 2001. - 28 p.

7. Consumption of addictive substances in mariners / R. Pougnet, L. Pougnet, B. Loddé [et al.] // Int Marit Health. - 2014. Vol. 65, Issue 4. - P. 199-204.

8. Fort E. Alcohol and nicotine dependence in French seafarers / E. Fort, A. Massardier-Pilonchery, A. Berget // International Maritime Health. - 2009. - Vol. 60 (1-2). - P. 18-28. 
9. Fort E. Psychoactive substances consumption in French fishermen and merchant seamen / E. Fort, A. MassardierPilonchéry, A. Bergeret // Int. Arch. Occup. Environ. Health. - 2010. - Vol. 83 (5). - P. 497-509. DOI: 10.1007/s00420-0090473-y

10. Jeżewska M. Stress and fatigue at sea versus quality of life / M. Jeżewska, R. Iversen // Int Marit Health. - 2012. Vol. 63 (3). - P. 106-115.

11. Prevalence of consumption of addictive substances amongst Moroccan fishermen / O. Laraqui, S. Laraqui, N. Manar [et al.] // Int. Marit. Health. - 2017. - Vol. 68 (1). - P. 19-25. DOI: 10.5603/IMH.2017.0004

12. Prevalence of drug use in French seamen / E. Fort, A. Massardier-Pilonchéry, F. Facy, A. Bergeret // Addictive Behaviors. - 2012. - Vol. 37, Issue 3. - P. 335-338.

13. Psychological stress in seafarers: a review / A. Carotenuto, I. Molino, A. M. Fasanaro, F. Amenta // International Maritime Health. - 2012. - Vol. 63 (4). - P. 188-194.

14. Risk factors for fishermen's health and safety in Greece / E. Frantzeskou, A.N. Kastania, E. Riza [et al.] // Int. Marit Health. - 2012. - Vol. 63 (3). - P. 155-161.

15. Shafran L. M. Seafarers health savings competencies: goals, professional features, formation and development / L. M. Shafran, V. V. Golikova // Вісник Морської Медицини. - 2018. - № 3 (80). - C. 4-12.

16. Survey on smoking habits among seafarers / I. Grappasonni, S. Scuri, F. Petrelli [et al.] // Acta. Bio. Med. - 2019. Vol. 90, No. 4. - P. 489-497. Access mode : https://www.mattioli1885journals.com/index.php/actabiomedica/article/ view/9001

\section{References}

1. Markova, M., \& Savina, M. (2018). Porushennia zdorovia simi ta addyktyvna povedinka u zhinok (mekhanizmy formuvannia, vzaiemozviazky, systema psykholohichnoi korektsii) [Family health and addictive behavior in women (mechanisms of development, interrelations, system of psychological correction and psychoprophylactic support)]. Fundamental and Applied Researches in Practice of Leading Scientific Schools, 25 (1), 89-108 [in Ukrainian].

2. Markova, M.V., \& Savina, M.V. (2017). Test dlia vyiavlennia rozladiv, poviazanykh z zakhoplenistiu sportom (fitnesom) SPORT-UDIT (versiia "samozvit") dlia neprofesionaliv [Test for identifying sports related fitness (fitness) disorders SPORTUDIT (self-report version) for non-professionals]. Svidotstvo pro reiestratsiiu avtorskoho prava na tvir № 70682 vid 24.02.2017 r. - Certificate of Registration of Copyright for the Work No. 70682 from 24.02.2017 [in Ukrainian].

3. Linskiy, I.V., Minko A.I., Artemchuk, A.F., Grinevich, Ye.G., Markova, M.V., Musiyenko, G.A., ..., \& Vyglazova, O.V. (2009). Metod kompleksnoy otsenki addiktivnogo statusa individa i populyatsii s pomoshchyu sistemy AUDIT-podobnykh testov [Method for comprehensive assessment of the additive individual status and population using the audit-like test system]. Visnyk psykhiatrii ta psykhofarmakoterapii - Bulletin of Psychiatry and Psychopharmacotherapy, 2 (16), 56-70 [in Russian].

4. Haponov, K.D., Sosin, I.K., Honcharova, O.Yu., \& Markova, M.V. (2018). Sposib diahnostyky klinichnoi spetsyfiky i prohnozu perebihu alkoholnoi zalezhnosti u osib z riznym psykhotravmatychnym dosvidom i rivnem psykhosotsialnoho stresu [A method of diagnosis of clinical specificity and prognosis of alcohol dependence in persons with different psychotraumatic experience and level of psychosocial stress]. Informatsiynyi lyst MOZ Ukrainy - Information Sheet of the Ministry of Health of Ukraine, No. 249-2018 [in Ukrainian].

5. Shafran, L.M., \& Holikova, V.V. (2014). Fizioloho-hihiienichni osoblyvosti profesiinoi diialnosti moriakiv spetsializovanoho flotu [Physiological and hygienic features of professional activity of seamen of specialized fleet]. Ukrainskyi zhurnal z problem medytsyny pratsi - Ukrainian Journal of Occupational Health, 3 (40), 29-39 [in Ukrainian].

6. Babor, Th.F., Higgins-Biddle, J.C., Saunders, J.B., \& Monteiro, M.G. (2001). AUDIT. Alcohol Use Disorders Identification Test. WHO/MSD/MSB/01.6a Original: English Distribution: General.

7. Pougnet, R., Pougnet, L., Loddé, B., Canals, L., Bell, S., Lucas, D., \& Dewitte, J.-D. (2014). Consumption of addictive substances in mariners. Int. Marit. Health, 65, 4, 199-204.

8. Fort, E., Massardier-Pilonchery, A., \& Berget, A. (2009). Alcohol and nicotine dependence in French seafarers. International Maritime Health, 60 (1-2), 18-28.

9. Fort, E., Massardier-Pilonchéry, A., \& Bergeret, A. (2010). Psychoactive substances consumption in French fishermen and merchant seamen. Int. Arch. Occup. Environ. Health, 83 (5), 497-509. doi: 10.1007/s00420-009-0473-y

10. Jeżewska, M., \& Iversen, R. (2012). Stress and fatigue at sea versus quality of life. Int Marit Health, 63 (3), $106-115$.

11. Laraqui, O., Laraqui, S., Manar, N., Ghailan, T., Deschamps, F., \& Laraqui, C.H. (2017). Prevalence of consumption of addictive substances amongst Moroccan fishermen. Int. Marit. Health, 68 (1), 19-25. doi: 10.5603/IMH.2017.0004

12. Fort, E., Massardier-Pilonchéry, A., Facy, F., \& Bergeret A. (2012). Prevalence of drug use in French seamen. Addictive Behaviors, 37, 3, 335-338.

13. Carotenuto, A., Molino, I., Fasanaro, A.M., \& Amenta, F. (2012). Psychological stress in seafarers: a review. International Maritime Health, 63 (4), 188-194.

14. Frantzeskou, E., Kastania, A.N., Riza, E., Jensen, O.C., \& Linos, A. (2012). Risk factors for fishermen's health and safety in Greece. Int. Marit. Health, 63 (3), 155-161.

15. Shafran, L.M., \& Golikova, V.V. (2018). Seafarers health savings competencies: goals, professional features, formation and development. Visnyk Morskoi Medytsyny - Bulletin of Marine Medicine, 3 (80), 4-12.

16. Grappasonni, I., Scuri, S., Petrelli, F., Nguyen, C.T.T., Sibilio, F., Di Canio, M., ..., \& Amenta, F. (2019). Survey on smoking habits among seafarers. Acta. Bio. Med., 90, 4, 489-497. Retrieved from: https://www.mattioli1885journals.com/ index.php/actabiomedica/article/view/9001 


\section{ADDICTIVE STATUS OF REPRESENTATIVES OF COMMAND STAFF AND WORKERS OF THE MERCHANT FLEET WITH DIFFERENT LEVELS OF PSYCHOSOCIAL STRESS}

M. V. Markova ${ }^{1}$, K. A. Kosenko², K. D. Gaponov ${ }^{1,3}$

${ }^{1}$ Kharkiv Medical Academy of Postgraduate Education Kharkiv, Ukraine

2"Odesa Regional Medical Center of Mental Health" of Odesa Regional Council, Odesa, Ukraine

${ }^{3}$ Communal Non-profit Enterprise of Kharkiv Regional Council "Regional Narcological Dispensary", Kharkiv, Ukraine

Purpose: to investigate the intensity of addictive status in sailors of the merchant fleet with different levels of psychosocial stress, in order to determine the necessity of creating systemic measures for the protection of their mental health, specific for this contingent.

Materials and Methods. Based on informed consent in compliance with the principles of bioethics and deontology, 200 representatives of the merchant fleet were surveyed during 2016-2019: 110 members of the command staff and 90 workers. The study involved the use of clinical-psychopathological and psychodiagnostic methods.

Result. As a result of the research, it was found that the representatives of the merchant fleet during the postvoyage period increased intensity of the addictive status on objects of chemical and non-chemical origin, the level of which is directly associated with the severity of the psychosocial stress. The general trend of the dynamics of the addictive status in the representatives of the merchant fleet, both in terms of chemical and non-chemical origin, is an increase in the intensity of addictive realization with increasing psychosocial stress.

The addictive status intensity in workers of the merchant fleet is significantly higher than in the command staff (except for work), in all the addictive realization range and stress load ranges. Among persons with low psychosocial stress, regardless of professional specificity, the intensity of the addictive status with addictive objects of both chemical and non-chemical origin is within safe use, which is significantly different from the addictive status in persons with moderate and severe levels of psychosocial stress. The addiction by chemical objects (tobacco, coffee/tea) in persons with moderate psychosocial stress is expressed within the limits of harmful effects, with severe psychosocial stress - dangerous use, and non-chemical ones - within the limits of harmful effects, with increasing indicators associated with increasing psychosocial stress.

Conclusion. Identified patterns should be taken into account when developing specific measures of psychotherapy and psychoprophylaxis for this contingent, which is the perspective of this study.

KEY WORDS: sailors of long-distance voyages; command staff of merchant fleet; merchant fleet workers; psychosocial stress; addictive status.

Рукопис надійшов до редакції 31.01.2020 p.

\section{Відомості про авторів:}

Маркова Маріанна Владиславівна - доктор медичних наук, професор, профресор кафедри сексології, медичної психології, медичної і психологічної реабілітації Харківської медичної академії післядипломної освіти. Косенко Корнелія Артурівна - кандидат медичних наук, завідувач відділення КНП «Одеський обласний медичний центр психічного здоров'я» Одеської обласної ради; асистент кафедри психіатрії та наркології Одеського національного медичного університету.

Гапонов Костянтин Дмитрович - доктор медичних наук, доцент, директор Комунального некомерційного підприємства Харківської обласної ради «Обласний наркологічний диспансер», доцент кафедри наркології Харківської медичної академії післядипломної освіти. 